\title{
Pore-water in marine sediments associated to gas hydrate dissociation 2 offshore Lebu, Chile.
}

3

Carolina Cárcamo ${ }^{1,2}$, Iván Vargas-Cordero ${ }^{1}$, Francisco Fernandoy ${ }^{1}$, Umberta Tinivella ${ }^{3}$, Diego López-Acevedo ${ }^{4}$, Joaquim P. Bento ${ }^{5}$, Lucía Villar-Muñoz ${ }^{6}$, Nicole Foucher $^{1}$, Marion San Juan ${ }^{1}$, Alessandra Rivero ${ }^{1}$

\footnotetext{
${ }^{1}$ Universidad Andres Bello, Facultad de Ingeniería, Quillota 980, Viña del Mar, Chile

${ }^{2}$ Centro de Investigación Marina Quintay. CIMARQ. Facultad de Ciencias de la Vida. Universidad Andres Bello, Viña del Mar, Chile.

3 OGS Istituto Nazionale di Oceanografia e di Geofisica Sperimentale, Borgo Grotta Gigante 42/C 34010, Sgonico, Italy.

4 Universidad de Concepción, Departamento de Oceanografía, Programa COPAS Sur-Austral, Campus Concepción Víctor Lamas 1290, P.O. Box 160-C, Concepción, Chile

${ }^{5}$ Escuela de Ciencias del Mar, Pontificia Universidad Católica de Valparaíso, Av. Altamirano 1480, 2360007 Valparaíso, Chile.

${ }^{6}$ GEOMAR Helmholtz Centre for Ocean Research, Wischhofstr. 1-3, 24148 Kiel, Germany.
}

\section{ABSTRACT}

Gas hydrate occurrences along the Chilean margin has been documented, but the processes associated to fluid escapes originated by gas hydrate dissociation yet are unknown. Here, we report morphologies growing related to fluid migration in the continental shelf offshore western Lebu $\left(37^{\circ} \mathrm{S}\right)$ by analysing mainly geochemical features. In this study oxygen and deuterium stable water isotopes in pore water were measured. Knowledge was completed by analysing bathymetric data, biological and sedimentological data. From bathymetric interpretation a positive relief at $127 \mathrm{~m}$ below sea level was recognised; it is oriented $\mathrm{N} 55^{\circ} \mathrm{E}$ and characterised by five peaks. Moreover, enrichment values for $\delta^{18} \mathrm{O}$ (from 0.0 to $1.8 \%$ ) and $\delta D$ (from 0.0 to $5.6 \%$ ) were obtained. These are typical values related to hydrate melting during coring and post-sampling. The evident orientation of positive relief could be associated with faults and fractures reported by others authors, in which these structures constitute pathways for fluid migration from deep to shallow zones. Finally, benthic foraminifera observed in the core sample can be associated to seep areas. On the basis of theoretical modelling, we conclude that the positive relief correspond to mud growing processes related to gas hydrates dissociation and represent a key area to investigate fluid migration processes.
\end{abstract}

Keywords: gas hydrate dissociation, stable isotopes, pore water, mud growing, fluid migration 
Hydrol. Earth Syst. Sci. Discuss., https://doi.org/10.5194/hess-2018-362

Manuscript under review for journal Hydrol. Earth Syst. Sci.

Discussion started: 29 August 2018

(c) Author(s) 2018. CC BY 4.0 License.

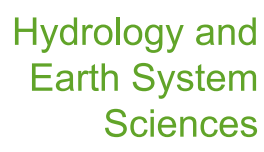

Discussions

\section{Introduction}

Morphological features associated with fluid escapes along continental margins (e.g.: mud volcanoes, mud mounds, pockmarks, seeps) have been worldwide reported (Van Rensbergen et al., 2002; Loncke et al., 2004; Hovland et al., 2005; Lykousis et al., 2009; Chen et al., 2010). Fluid escapes can be formed mainly by biogenic and thermogenic methane gas and water. The gas can give place to gas hydrate formation in marine sediments if pressure and temperature conditions are adequate (Sloan, 1998), in which the gas is trapped in a lattice of water molecules. Gas hydrate occurrences along the Chilean margin are distributed from 33 to $57^{\circ} \mathrm{S}$ (Bangs et al., 1993; Froelich et al., 1995; Morales, 2003; Grevemeyer et al., 2003; Rodrigo et al., 2009; Vargas-Cordero et al., 2010, 2010a, 2016, 2017; Villar-Muñoz et al., 2014, 2018). Several studies have documented fluid escapes related to gas hydrate dissociation through faults and fractures (e.g., Yin et al., 2003; Thatcher et al., 2013). Among others, common techniques often used to recognize such processes are: biological, geochemical and geophysical analyses. Biological indicators as benthic foraminifera, bivalve shells and microbial communities have been related with fluid escapes (Reed et al., 2002; Chen et al., 2007; Karstens et al., 2018). Moreover, enriched stable water isotope values have been measured from pore water of marine sediments. Hesse (2003) and Kvenvolden and Kastner (1990) reported in extensive articles several cases of enriched stable water isotope values from different regions, including the Chilean coast. Finally, geophysical studies have allowed identifying morphologies associated with fluid escapes by using bathymetric, backscatter and high resolution images (Sager et al., 2003; Loncke et al., 2004; Tinivella et al., 2007). Well and seismic data interpretations have allowed recognizing active structural domain offshore Arauco basin (Melnick and Echtler, 2006; Melnick, 2006a). During the depositional history of Arauco Basin, numerous tectonic phases have been recognized, including subsidence and uplift episodes that gave place to accretion and erosion of the prism (Bangs and Cande, 1997; Lohrmann, 2002).Cretaceous-Plio-Pleistocene marine and continental sequences configure a cyclic sedimentary complex. Sedimentary sequences are composed by alternating of marine and continental deposits. From base to top, these are: Quiriquina (Biró-Bagóczky, 1982), Pilpilco, Curanilahue, Boca Lebu, Trihueco, Millongue, Ranquil, Tubul and Arauco formations (Pineda, 1983; Viyetes et al., 1993; Muñoz-Cristi, 1956; Muñoz-Cristi, 1968). Nahuelbuta Range is composed by Carboniferous-Permian granitoides (Coastal Batholith) intruding the PaleozoicMesozoic metamorphic rocks. Moreover, gas and carbon reservoirs have been identified along the Arauco basin (Mordojovich, 1974; González, 1989).

This study aims at characterizing an identified positive relief in order to understand its origin by using geochemical, sedimentological and bathymetric data. The study area is located on continental shelf close to $150 \mathrm{~m}$ below sea level (mbsl) and includes part of Arauco basin (Fig. 1).

\section{Data and Methods}

\subsection{Data}


In the framework of project entitled "Identification and quantification of gas emanations associated with gas hydrates (FONDECYT 11140214)" sedimentological, geochemical and bathymetric study offshore Lebu was performed (Fig. 1). In 2016 and 2017 two marine campaigns onboard R/V Kay Kay II were carried out collecting bathymetric data, seawater samples and marine sediments Marine sediment samples were recovered by using gravity corer (diameter of $9 \mathrm{~cm}$ ) at around $127 \mathrm{mbsl}$ and the gravity corer drilled as deep as $240 \mathrm{~cm}$ into marine sediments (GC-02). The core collected is located around positive relief close to $73^{\circ} 44^{\prime} 25^{\prime \prime} \mathrm{W}-37^{\circ} 36^{\prime} 10^{\prime \prime} \mathrm{S}$ (Fig. 2). The GC-02 core was divided into four sections of $60 \mathrm{~cm}$ long (S01, S02, S03, S04); each section one was frozen and analysed at Sedimentology Andres Bello University's laboratory (Viña del Mar, Chile)

The water samples were collected by Niskin bottles at 5 depths $(0 \mathrm{~m}, 10 \mathrm{~m}, 20 \mathrm{~m}$, $50 \mathrm{~m}$ and bottom); temperature, conductivity, dissolved oxygen and $\mathrm{pH}$ was determined with multiparameter measurer model IP67. These parameters were measured at the two ends of the identified lineament, i.e., the first station located to the south and the second one to the north (Fig. 2).

\subsection{Methods}

The procedure includes: a) bathymetric data processing and b) sedimentological, physical-chemical and geochemical analyses of seawater and marine sediment samples.

Bathymetric and sound velocity data were acquired by using multihaz Reson SeaBat 7125 echosounder $\left(400 \mathrm{kHz}, 0.5^{\circ} \times 1^{\circ}\right)$ and SVP90 probe, respectively. Besides, an AML Oceanographic Model Minos X sound velocity profiler was used. A preliminary processing was performed onboard by using PDS2000 commercial software. This software allows correcting bathymetric data in real time by using SVP90 and AML information and ship motions (pitch, roll, yaw and heave). The bathymetric data processing was performed by using open-source MB-System software (Caress and Chayes, 2017). In this step, bathymetric data were converted in MB-System format in order to attenuate tide and scattering effects. In the first step, bathymetric grids with nearneighbor interpolation algorithm were created by using open-source software Generic Mapping Tools (GMT, Wessel et al., 2013). The algorithm builds cell values in depth rectangular distributed, in which each node value corresponds to the weighted average of around probes of search circle of 1 arc second. Besides the selected grid was configured with spatial resolution of 0.2 arc seconds. Finally, a median filter of $10 \mathrm{~m}$ width was applied in order to smooth the grid.

Grain size analysis includes sieving method where sediments pass through (by agitation) meshes; in our case, $50 \mathrm{~g}$ of sediment sample were sieved by using the following mesh sizes: $60,80,120$ and 230 . The pipette method was adopted in order to separate clay and silt fractions by selecting $15 \mathrm{~g}$ of mud sample. Statistical parameters were calculated in agreement with reported formulas (Folk and Ward, 1957; Carver, 1971; Scasso and Limarino, 1997). 
Seawater physical-chemical properties (temperature, $\mathrm{pH}$, salinity and dissolved oxygen) in proximity of the positive relief were obtained by using the multiparameter Meter (IP67, model 8602). The multiparameter Meter has different types of probes or electrodes, which must be selected according to the required function and to obtain accurate measurements. Temperature was measured in Celsius degree, with an accuracy of $+10.5^{\circ} \mathrm{C}$, while $\mathrm{pH}$ was directly related to the ratio of the concentrations of hydrogen ions $[\mathrm{H}+]$ and hydroxyl $[\mathrm{OH}]($ Cabo, 1978) with an accuracy of $+/-0.1$. Salinity was obtained from the conductivity, which depends on the number of dissolved ions per unit volume and the mobility of the ions; the accuracy is $+/-0.1$. Finally, dissolved oxygen can be measured both in $\%$ and in $\mathrm{mg} / \mathrm{L}$, with accuracy $+/-3 \%$; in our case, it was expressed in $\%$.

The core was cut in sections of $10 \mathrm{~cm}$ long and then the main physical-chemical parameters were measured including pore water $(w \%)$, porosity $(\Phi)$, the content of solid material per unit volume, expressed as apparent density ( $\rho$; Salamanca and Jara, 2003) and total organic matter (TOC). Finally, samples were dried in forced air oven at $60^{\circ} \mathrm{C}$ for 36 hours and in a desiccator for 30 minutes.

TOC content was measured by gravimetric determination of weight loss through loss-on-ignition method (Byers et al., 1978; Luczak et al., 1997). In our case, $2 \mathrm{~g}$ of dry sediment sample was calcined in muffle at $500{ }^{\circ} \mathrm{C}$ for 5 hours and, then, it was placed in desiccator for 30 minutes until to register constant weight in order to reduce the associated error. Pore water from core was extracted using an ACME lysimeter $(0.2 \mu \mathrm{m})$ in order to analyse oxygen and deuterium stable water isotopes. The pore water extraction procedure includes: a) corer cutting in sections of $5 \mathrm{~cm}$ long, b) centrifugation, c) pore water extraction by using Rhizon MOM with pore sizes ranging to 0.12 to $0.18 \mu \mathrm{m}$ and d) stable water isotope determination by Cavity Ring Down Spectroscopy (CRDS) method at the Laboratorio de Análisis Isotópico (LAI) at the Universidad Andrés Bello (Viña del Mar, Chile).

Oxygen and deuterium water isotope analyses were evaluated using LIMS (Coplen and Wassenaar, 2015) and normalized to the VMSOW-SLAP scale and reported as $\delta$-values for oxygen $\left(\delta^{18} \mathrm{O}\right)$ and deuterium $(\delta \mathrm{D})$.

\section{Results}

From bathymetric data, a positive relief located at $127 \mathrm{mbs}$ with orientation $\mathrm{N} 55^{\circ} \mathrm{E}$ was recognised. The relief shows an elevation of about $6 \mathrm{~m}$ above the seafloor, an extension of $700 \mathrm{~m}$ length and a width of $50 \mathrm{~m}$ (Fig. 2). Five peaks along the relief were observed.

Grain size analysis shows a constant values in depth. The average grain size value corresponds to sandy mud textural group. Silt size reaches $60 \%$ of total volume (Fig. 3). Physical-chemical parameter distribution of core GC-02 are detailed in Table 1. A slightly variation of water content (average equal to $43.1 \%$ ), apparent density (average equal to $1.6 \mathrm{~g} / \mathrm{cm}^{3}$ ) and porosity (average equal to $66.9 \%$ ) were detected. 
Hydrol. Earth Syst. Sci. Discuss., https://doi.org/10.5194/hess-2018-362

Manuscript under review for journal Hydrol. Earth Syst. Sci.

Discussion started: 29 August 2018

(c) Author(s) 2018. CC BY 4.0 License.

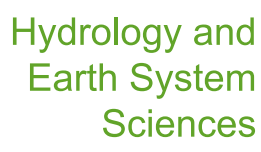

Discussions located at $2.2 \mathrm{~m}$, while the minimum value is equal to $5.1 \%$ of total volume detected at $0.4 \mathrm{~m}$ (Fig. 4).

Pore stable water isotope analysis of marine sediment core shows positive values ranging from 0.0 up to $+1.8 \%$ for of $\delta^{18} \mathrm{O}$ and $5.6 \%$ for $\delta \mathrm{D}$, respectively (Fig 5 ). Stable water isotope $\delta$-values show a positive trend (enrichment) towards the bottom of the sediment core, with values close to 0 at the top in the sediment-water interface, and a restricted variability for all samples analysed (Std. Dev. 0.33 and 0.95 for $\delta^{18} \mathrm{O}$ and $\delta D$, respectively). It should be noticed that no negative values were found along the core.

Benthic foraminiferal accumulations in shallow level of core $(0-60 \mathrm{~cm})$ showing globose and elongated morphologies. The following genders of opportunistic foraminifera were recognized: Globobulimina, Bolivina, Valvulineria, Anomalinoides, Uvigerina, Oridorsalis and Quinqueloculina (Fig. 6).

Temperature values range from 12 to $14^{\circ} \mathrm{C}$ in seawater samples, registering maximum values in correspondence of shallow levels, while minimum values were found in deep levels. Salinity and dissolved oxygen values show a similar trend with maximum values equal to $33 \%$ and $60 \%$ located at $20 \mathrm{mbsl}$, respectively. Minimum values of salinity (31\%) and dissolved oxygen (66.2\%) were measured in station 1 at $0.6 \mathrm{mbsl}$, respectively. $\mathrm{pH}$ values range from 7.5 to 8.1 (Fig. 5).

\section{Discussion and conclusion}

The stable water isotope composition of pore water represents a strong evidence of gas-hydrate dissociation. Figure $5 \mathrm{a}$ shows the stable water isotope profile of the entire core, showing an evident trend with values close to $0 \%$ at water-sediment interface to positive values at the bottom of the core $\left(\sim 2 \%\right.$ and $6 \%$ for $\delta^{18} \mathrm{O}$ and $\delta \mathrm{D}$, respectively). This trend shows the influence of sea-water mixing on the top and a different source at the bottom of the core. Positive values of meteoric waters are mostly associated to high evaporation rates, which could be discarded in the context of this investigation. Positive $\delta^{18} \mathrm{O}$ values have been reported for clay minerals dewatering; however in this case a $\delta \mathrm{D}$ depletion rather than enrichment is expected (Hesse, 2003). Nonetheless, the co-isotope relationship (Fig. 5b) of our samples shows that pore waters stable water composition have a positive correlation (i.e.: simultaneous enrichment of $\delta^{18} \mathrm{O}$ and $\delta \mathrm{D}$ ). Additionally, the meteoric origin of the pore water can be rejected as shown in Fig. $5 c$, as pore waters fall away from the Global Meteoric Water Line (GMWL), which defines the fractionation processes during the hydrological cycle (Craig, 1961). Stable water isotope enrichment of pore has been related to hydrate melting during coring and post-sampling (Hesse, 2003; Tomaru et al., 2006), which are preferentially enriched by heavy stable water isotope.

The infaunal foraminifera, found in the shallower sediment sample (e.g Bolivina and Uvigerina), could be associated with modern cold seep, since they can be metabolising seeping methane, directly or indirectly exploiting the available geochemical energy source (Jones, 2014). Besides, benthic foraminifera are 
Hydrol. Earth Syst. Sci. Discuss., https://doi.org/10.5194/hess-2018-362

Manuscript under review for journal Hydrol. Earth Syst. Sci.

Discussion started: 29 August 2018

(c) Author(s) 2018. CC BY 4.0 License.

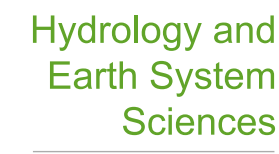

Discussions associated with high organic content ambient, low oxygen conditions and cold seep occurrences (Hill et al, 2003; Rathburn et al. 2000).

In the study area across the continental slope zone, gas phases concentrations were estimated by Vargas et al. (2010a), reporting $15 \%$ of total volume for hydrates and $0.2 \%$ of total volume for free gas. Several studies argue that lateral fluid migration can occur from deep levels through faults and fractures canalising fluids and giving place to mud mounds and mud volcanoes (Yin et al., 2003; Thatcher et al., 2013). Other studies in our study area have reported faults extending wards offshore zones (Melnick et al., 2009; Vargas-et al., 2011; Becerra et al., 2013). Moreover, gas accumulations can reach shallow areas because the base of gas hydrate stability zone (GHSZ) can be very shallow in the continental shelf, as indicated by theoretical modelling. In fact, in order to understand where the gas hydrate is stable versus seawater depth, the theoretical base of the GHSZ was calculated assuming a geothermal gradient of $30 \mathrm{~km} /{ }^{\circ} \mathrm{C}$ (in agreement with Vargas-Cordero et al., 2010a) and a mixture of $95 \%$ of methane and $5 \%$ of ethane (in agreement with measures at ODP Site 1235). Details about the method are reported in Vargas-Cordero et al. (2017). Note that seismic data acquired in our study area detected the presence of the hydrate and the free gas, confirming that this area is characterized by relevant upward fluid flow (Vargas-Cordero et al., 2010a). As shown in Fig. 7, the theoretical base of GHSZ reaches the seafloor at a seawater depth of about $400 \mathrm{~m}$; so, at shallower seawater depth the hydrate is not stable and only free gas can be present. Note that in our study area the continental shelf is shown narrow (15 km width) favouring that fluids associated to gas hydrate dissociation and gas accumulations can migrate wards shallow areas from the base of GHSZ. It is important to notice that in other areas at high latitudes, an extent reduction of the GHSZ, was observed due to the warming over the last 20000 years (i.e., Westbrook et al., 2009; Thatcher et al., 2013). To verify a similar trend in our study area, we modelled the theoretical base of the GHSZ supposing past temperature conditions reported by paleoclimatic reconstruction studies (Kim et al., 2002; Lamy and Kayser, 2009), i.e. a decrease of the seawater bottom temperature of $1^{\circ} \mathrm{C}, 2^{\circ} \mathrm{C}, 3^{\circ} \mathrm{C}, 4^{\circ} \mathrm{C}$, and $5^{\circ} \mathrm{C}$ (Fig. 7). The modelling indicates that the origin of the mud structures analysed in this paper can be related to hydrate dissociation caused by the increase of seawater bottom temperature in the past.

Grain size results can be associated with flow hydrodynamic conditions, in which mud and sand could be related with coastal and beach systems, fluvial or deltaic deposits (Mordojovich, 1981). Slightly vertical variations allow us to define a relationship between physical-chemical parameters (W, $\Phi, \rho$ and MOT) and grain sizes results. Studies reported by Pineda (2009) argue that clay and silt presence in marine sediments are capable to retain organic wastes increasing TOC values. The values ranging from 0.5 to $10 \%$ reported by Pineda (2009) are in agreement with values presented in this study.

The results of the seawater analysis show typical values of temperature, salinity, dissolved oxygen and $\mathrm{pH}$, which are associated with seawater masses. The temperature in the seawater column increases in shallow levels, whereas it 
decreases in deep levels. An opposite trend regarding salinity and dissolved oxygen values were recognized; in effect, when the oxygen solubility decreases, the temperature and salinity increases (Cabo, 1978). The $\mathrm{pH}$ values ranging from 7.4 to 8.4 can be associated with seawater alkalinity. The highest values are often detected on the seawater surface (Cabo, 1978). No relationships between seawater physicalchemical parameters and our conclusion were found, which can be explained due to: a) discrete data collected (e.g five seawater samples were collected in a column of $130 \mathrm{~m}$ ) or b) upwelling and downwelling processes reported in this area (Parada et al., 2012) could give place to water mass exchange preventing to observe significant variations.

We can conclude that the positive relief can be associated with mud mound growing by fluid flux supply canalised by faults and fractures. These fluids probably are related to gas hydrates dissociation, in which gas and water migrate from deeper to shallower areas.

\section{Acknowledgements}

We are grateful to CONICYT (Fondecyt de Iniciación N¹1140216), which partially supported this work. The authors are grateful to Michela Giustiniani for constructive discussions and useful comments. Special thanks to Mauricio and Daniel from the palaeontology laboratory (UNAB - Viña del Mar), who helped us with the foraminifera identification.

\section{References}

Bangs, N. L. and Cande, S. C.: Episodic development of a convergent margin inferred from structures and processes along the southern Chile margin, Tectonics, 16 (3), $489-503,1997$.

Bangs, N. L., Sawyer, D. S., and Golovchenko, X.: Free gas at the base of the gas hydrate zone in the vicinity of the Chile triple junction, Geology, 21(10), 905-908, 1993.

Becerra, J., Contreras-Reyes, E., and Arriagada, C.: Seismic structure and tectonics of the southern Arauco Basin, south-central Chile ( 38S), Tectonophysics, 592, 5366, 2013.

Biró-Bagóczky, L.: Revisión y redefinición de los estratos de Quinquina, Campaniano-Maestrichtiano, en su localidad tipo, en la Isla Quinquina, $36^{\circ} 37^{\prime}$ Lat. Sur. Chile, Sudamérica. Actas III Congreso Geológico Chileno, tomo I(A), 29-64, 1982. 
Byers S., Mills, E. \& Stewart, P.: A comparison of methods of determining organic carbon in marine sediments, with suggestions for a standard method, Hidrobiología, 58(1), 43-47, 1978.

Cabo, F.: Oceanografía, biología marina y pesca, Editorial Paraninfo S.A., Madrid, España, 1978.

Caress, D. W. and Chayes, D. N.: MB-System (versión 5.5.2298), Mapping the seafloor, http://www.Ideo.columbia.edu/MB-System/html/mbsystem_home.html, 2017.

Carver, R. E.: Procedures in Sedimentary Petrology, Wiley-Interscience, 1971.

Chen, Y., Matsumoto, R., Paull, C. K., Ussler III, W., Lorenson, T., Hart, P., and Winters, W.: Methane-derived authigenic carbonates from the northern Gulf of Mexico-MD02 Cruise, Journal of Geochemical Exploration, 95(1-3), 1-15, 2007.

Chen, S. C., Hsu, S. K., Tsai, C. H., Ku, C. Y., Yeh, Y. C., and Wang, Y.: Gas seepage, pockmarks and mud volcanoes in the near shore of SW Taiwan, Marine Geophysical Researches, 31(1-2), 133-147, 2010.

Coplen, T., and Wassenaar, L.: LIMS for Lasers 2015 for achieving long-term accuracy and precision of $\delta^{2} \mathrm{H}, \delta^{17} \mathrm{O}$, and $\delta^{18} \mathrm{O}$ of waters using laser absorption spectrometry, rapid communications in mass spectrometry, 29, 2122-2130, 10.1002/rcm.7372, 2015.

Craig, H.: Isotopic variations in meteoric waters, Science, 133, 1702-1703, doi: 10.1126/science.133.3465.1702, 1961.

Folk, R.L., and Ward, W.C.: A Study in the Significance of Grain-Size Parameters, Journal of Sedimentary Petrology, 27, 3-26, 1957.

Froelich, P. N., Kvenvolden, K. A., Torres, M. E., Waseda, A., Didyk, B. M., and Lorenson, T. D.: Geochemical evidence for gas hydrate in sediment near the Chile Triple Junction, 1995.

González, E.: Hydrocarbon Resources in the Coastal Zone of Chile, Geology of the Andes and its relation to hydrocarbon and mineral resources, Earth Science Series, 11, 383-404. Circum-Pacific Council for Energy and Mineral Resources. Houston, Texas, 1989.

Grevemeyer, I., Diaz-Naveas, J. L., Ranero, C. R., and Villinger, H. W.: Heat flow over the descending Nazca plate in central Chile, $32 \mathrm{~S}$ to $41 \mathrm{~S}$ : Observations from ODP Leg 202 and the occurrence of natural gas hydrates, Earth and Planetary Science Letters, 213(3-4), 285-298, 2003.

Hesse, R.: Pore water anomalies of submarine gas-hydrate zones as tool to assess hydrate abundance and distribution in the subsurface: What have we learned in the 
past decade?, Earth-Science Reviews, 61, 149-179, doi: 10.1016/S00128252(02)00117-4, 2003.

Hill, T. M., Kennett, J. P., and Spero, H. J.: Foraminifera as indicators of methanerich environments: A study of modern methane seeps in Santa Barbara Channel, California, Marine Micropaleontology, 49(1-2), 123-138, 2003.

Hovland, M., Svensen, H., Forsberg, C. F., Johansen, H., Fichler, C., Fosså, J. H., and Rueslåtten, H.: Complex pockmarks with carbonate-ridges off mid-Norway: products of sediment degassing, Marine geology, 218(1-4), 191-206, 2005.

Jones, R.W.: Foraminifera and their Applications, Cambridge University Press, 2014.

Karstens, J., Haflidason, H., Becker, L. W., Berndt, C., Rüpke, L., Planke, S., and Mienert, J.: Glacigenic sedimentation pulses triggered post-glacial gas hydrate dissociation, Nature communications, 9(1), 635, 2018.

Kim, J. H., Schneider, R. R., Hebbeln, D., Müller, P. J., and Wefer, G.: Last deglacial sea-surface temperature evolution in the Southeast Pacific compared to climate changes on the South American continent, Quaternary Science Reviews, 21(18), 2085-2097, 2002.

Kvenvolden, K. A., and Kastner, M.: Gas hydrates of the peruvian outer continental margin, Proceedings of the Ocean Drilling Program, Scientific Results, 112, 515526, 1990.

Lamy, F., and Kaiser, J.: Glacial to Holocene paleoceanographic and continental paleoclimate reconstructions based on ODP Site 1233/GeoB 3313 off southern Chile, In Past Climate Variability in South America and Surrounding Regions, 129156, 2009.

Lohrmann, J.: Identification of Parameters Controlling the Accretive and Tectonically Erosive Mass - Transfer Mode at the South - Central and North Chilean Forearc Using Scaled 2D Sandbox Experiments, PHD Thesis, 2002.

Loncke, L., Mascle, J., and Parties, F. S.: Mud volcanoes, gas chimneys, pockmarks and mounds in the Nile deep-sea fan (Eastern Mediterranean): geophysical evidences, Marine and petroleum geology, 21(6), 669-689, 2004.

Luczak C., Janquin M., and A Kupka, A.: Simple standard procedure for the routine determination of organic matter in marine sediment, Hidrobiología, 345, 87-94, 1997.

Lykousis, V., Alexandri, S., Woodside, J., De Lange, G., Dählmann, A., Perissoratis, C., and Rousakis, G.: Mud volcanoes and gas hydrates in the Anaximander 
mountains (Eastern Mediterranean Sea), Marine and Petroleum Geology, 26(6), 854-872, 2009.

Melnick, D., and Echtler, H.: Inversion of forearc basins in southcentral Chile caused by rapid glacial age trench fill, Geology, 34(9), 709-712, 2006.

Melnick, D., Bookhagen, B., Echtler, H. P., Strecker, M. R.: Coastal deformation and great subduction earthquakes, Isla Santa María, Chile (37 S), Geological Society of America Bulletin, 118(11-12), 1463-1480, doi: https://doi.org/10.1130/B25865.1, 2006a.

Melnick, D., Bookhagen, B., Strecker, M. R., \& Echtler, H. P.: Segmentation of megathrust rupture zones from fore-arc deformation patterns over hundreds to millions of years, Arauco peninsula, Chile, Journal of Geophysical Research: Solid Earth, 114(B1), 2009.

Morales, G.: Methane hydrates in the Chilean continental margin, Electronic Journal of Biotechnology, 6(2), 80-84, doi: 10.4067/S0717-34582003000200002, 2003.

Mordolovich, C.: Geology of a Part of the Pacific Margin of Chile, The Geology of Continental Margins, 591-598, 1974.

Mordojovich, C.: Sedimentary basins of the Chilean Pacific offshore, Energy Resources of the Pacific Region, American Association of Petroleum Geo, 2, 63-82, 1981.

Muñoz-Cristi, J.: Geological Society of America Memoirs, Chile, 187-215, 1956.

Muñoz Cristi, J.: Contribución al conocimiento geológico de la región situada al Sur de Arauco y partición del material volcánico en los sedimentos Eocenos en el Terciario de Arauco (G. Cecioni Ed), Ed. Andrés Bello, Santiago, 63-94, 1968.

Parada, C., Colas, F., Soto-Mendoza, S., and Castro, L.: Effects of seasonal variability in across-and alongshore transport of anchoveta (Engraulis ringens) larvae on model-based pre-recruitment indices off central Chile, Progress in oceanography, 92, 192-205, 2012.

Pineda, V.: Evolución Paleogeográfica de la Península de Arauco durante el Cretácico Superior - Terciario, Tesis de grado para optar al título de geólogo. Universidad de Concepción, Chile, 1983.

Pineda, V.: Granulometría y geoquímica de los sedimentos marinos en el área comprendida entre el seno de Reloncaví y golfo Corcovado, Chile, Crucero CIMAR 10 fiordos, Revista ciencia y tecnología del mar, 32 (1), 27-47, 2009. 
Rathburn, A. E., Levin, L. A., Held, Z., and Lohmann, K. C.: Benthic foraminifera associated with cold methane seeps on the northern California margin: Ecology and stable isotopic composition, Marine Micropaleontology, 38(3-4), 247-266, 2000.

Reed, D. W., Fujita, Y., Delwiche, M. E., Blackwelder, D. B., Sheridan, P. P., Uchida, T., and Colwell, F. S.: Microbial communities from methane hydrate-bearing deep marine sediments in a forearc basin, Applied and Environmental Microbiology, 68(8), 3759-3770, 2002.

Rodrigo, C., González-Fernández, A., and Vera, E.: Variability of the bottomsimulating reflector (BSR) and its association with tectonic structures in the Chilean margin between Arauco Gulf (37 S) and Valdivia (40 S), Marine Geophysical Researches, 30(1), 1-19, 2009.

Sager, W. W., MacDonald, I. R., and Hou, R.: Geophysical signatures of mud mounds at hydrocarbon seeps on the Louisiana continental slope, northern Gulf of Mexico, Marine Geology, 198(1-2), 97-132, 2003.

Salamanca, M., and Jara, B.: Distribución y acumulación de plomo ( $\mathrm{Pb}$ y ${ }^{210} \mathrm{~Pb}$ ) en sedimentos de los fiordos de la XI región, Chile, Revista ciencia y tecnología del mar, 26 (2), 61-71, 2003.

Scasso, R.A., and Limarino, C.O.: Petrología y diagénesis de rocas clásticas, Asociación Argentina de Sedimentología, Publicación Especial Nro: 1, 257, 1997.

Shipboard Scientific Party: Site 1235, In Mix, A.C., Tiedemann, R., Blum, P., et al., Proc. ODP, Init. Repts., 202: College Station, TX (Ocean Drilling Program), 1-68, doi:10.2973/odp.proc.ir.202.106.2003, 2003

Sloan Jr, E. D.: Clathrate Hydrates of Natural Gases, revised and expanded, Crc Press, 1998.

Thatcher, K. E., Westbrook, G. K., Sarkar, S., and Minshull, T. A.: Methane release from warming-induced hydrate dissociation in the West Svalbard continental margin: Timing, rates, and geological controls, Journal of Geophysical Research: Solid Earth, 118(1), 22-38, 2013.

Tinivella, U., Accaino, F., and Della Vedova, B.: Gas hydrates and active mud volcanism on the South Shetland continental margin, Antarctic Peninsula, Geo-Mar Lett, doi: s00367-007-0093-z, 2007.

Tomaru, H., Torres Marta, E., Matsumoto, R., and Borowski Walter, S.: Effect of massive gas hydrate formation on the water isotopic fractionation of the gas hydrate system at Hydrate Ridge, Cascadia margin, offshore Oregon, Geochemistry, Geophysics, Geosystems, 7, doi: 10.1029/2005GC001207, 2006. 
Van Rensbergen, P., De Batist, M., Klerkx, J., Hus, R., Poort, J., Vanneste, M., and Krinitsky, P.: Sublacustrine mud volcanoes and methane seeps caused by dissociation of gas hydrates in Lake Baikal, Geology, 30(7), 631-634, 2002.

Vargas-Cordero, I., Tinivella, U., Accaino, F., Loreto, M. F., Fanucci, F.: Thermal state and concentration of gas hydrate and free gas of Coyhaique, Chilean Margin (44 30' S), Marine and Petroleum Geology, 27(5), 1148-1156, 2010.

Vargas-Cordero, I., Tinivella, U., Accaino, F., Loreto, M. F., Fanucci, F., and Reichert, C.: Analyses of bottom simulating reflections offshore Arauco and Coyhaique (Chile), Geo-Marine Letters, 30(3-4), 271-281, doi: 10.1007/s00367-0090171-5, 2010a.

Vargas-Cordero, I., Tinivella, U., and Accaino, F.: Basal and Frontal Accretion Processes versus BSR Characteristics along the Chilean Margin, Journal of Geological Research, Article ID 846101, 10, doi: 10.1155/2011/846101, 2011.

Vargas Cordero, I., Tinivella, U., Villar Muñoz, L., and Giustiniani, M.: Gas hydrate and free gas estimation from seismic analysis offshore Chiloé island (Chile), Andean Geology, 43(3), 263-274, doi: 10.5027/andgeoV43n3-a02, 2016.

Vargas-Cordero, I., Tinivella, U., and Villar-Muñoz, L.: Gas Hydrate and Free Gas Concentrations in Two Sites inside the Chilean Margin (Itata and Valdivia Offshores), Energies, 10(12), 2154-2165, doi: 10.3390/en10122154, 2017.

Villar-Muñoz, L., Behrmann, J. H., Diaz-Naveas, J., Klaeschen, D., and Karstens, J.: Heat flow in the southern Chile forearc controlled by large-scale tectonic processes, Geo-Marine Letters, 34(2-3), 185-198, 2014.

Villar-Muñoz, L., Bento, J. P., Klaeschen, D., Tinivella, U., Vargas-Cordero, I., Behrmann, J. H.: A first estimation of gas hydrates offshore Patagonia (Chile). Marine and Petroleum Geology, doi: 10.1016/j.marpetgeo.2018.06.002, 2018.

Vieytes, H., Arcos, R. and González. A.: Interpretación en la exploración en la Cuenca de Arauco: Sector Continental, Informe inédito Enap-Santiago, Santiago, Chile, 1993.

Wessel, P., Smith, W. H. F., Scharroo, R., Luis, J. F., and Wobbe, F.: Generic Mapping Tools: Improved version released, EOS Trans. AGU, 94, 409-410, 2013. Westbrook, G. K., Thatcher, K. E., Rohling, E. J., Piotrowski, A. M., Pälike, H., Osborne, A. H., and Hühnerbach, V.: Escape of methane gas from the seabed along the West Spitsbergen continental margin, Geophysical Research Letters, 36(15), 2009.

Yin, P., Berne, S., Vagner, P., Loubrieu, B., and Liu, Z. Mud volcanoes at the shelf margin of the East China Sea, Marine Geology, 194(3-4), 135-149, 2003. 
Hydrol. Earth Syst. Sci. Discuss., https://doi.org/10.5194/hess-2018-362

Manuscript under review for journal Hydrol. Earth Syst. Sci.

Discussion started: 29 August 2018

(c) Author(s) 2018. CC BY 4.0 License.
Hydrology and

Earth System

Sciences

Discussions
521

522

523

524

525

\section{Figures}

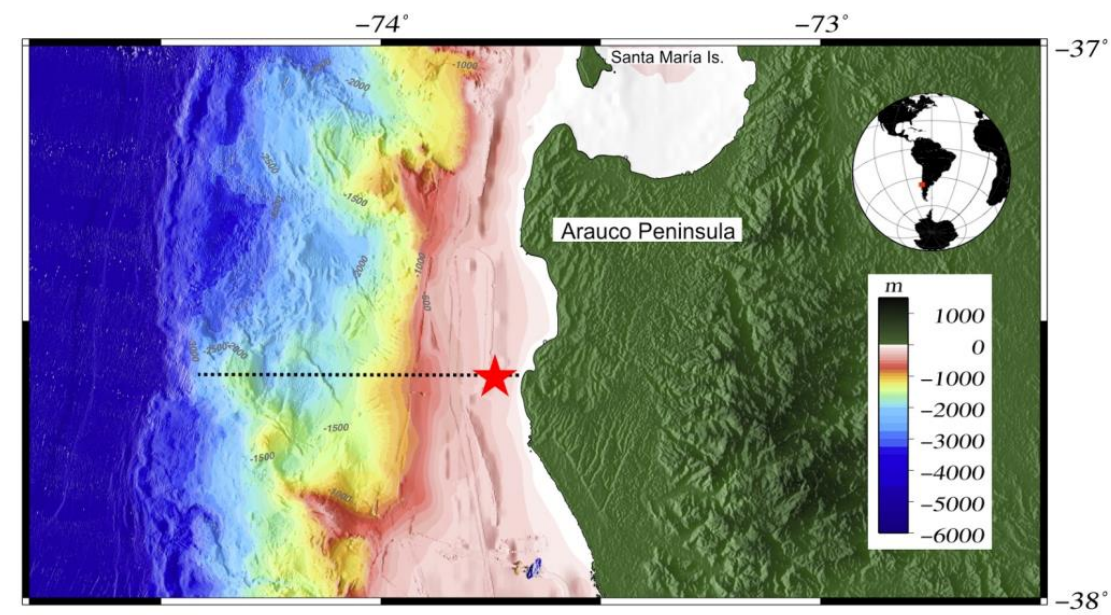

Figure 1: Location map of the studied area. Red star shows core recovery and bathymetric survey. Dashed line shows the bathymetric profile used in Fig. 7 .

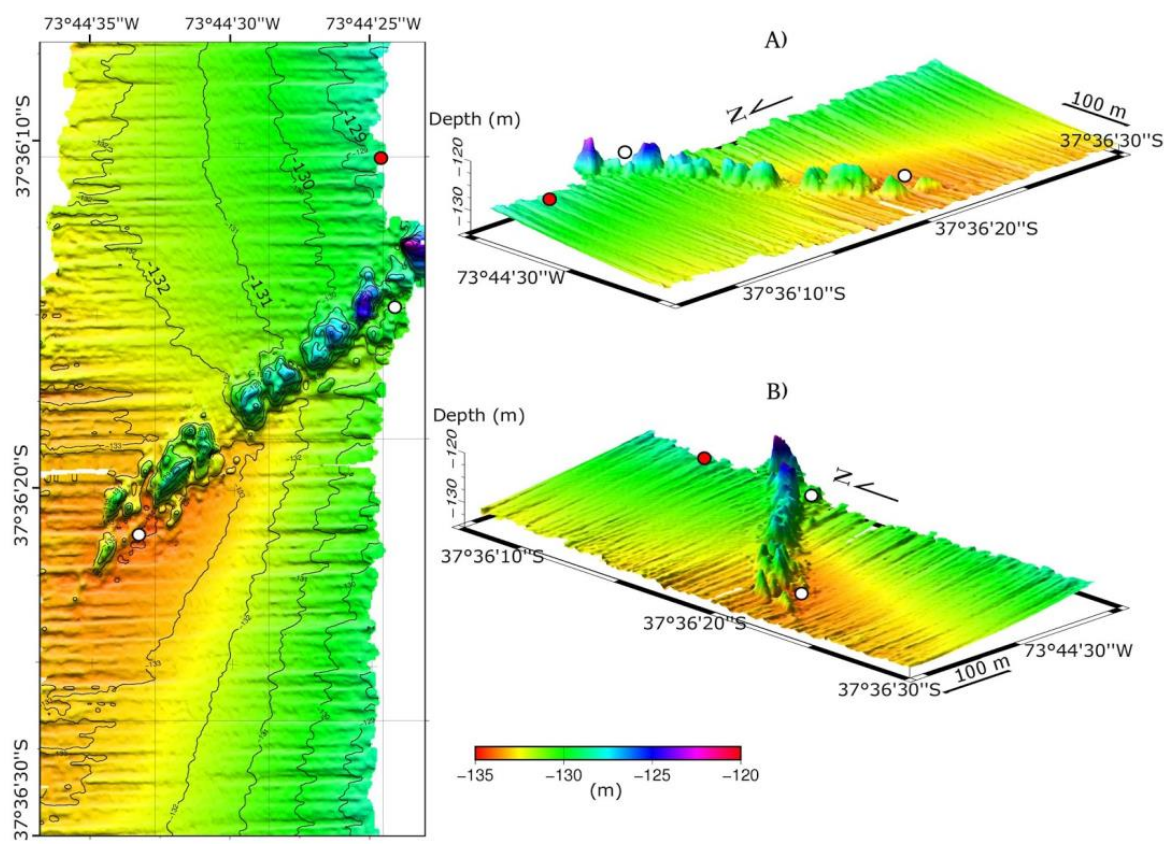

Figure 2: Bathymetric map indicating location core GC-02 (red circle). In A) and B) $3 \mathrm{D}$ images with orientation NW and SW respectively. The white circles indicate the position of the two water samples. 
Hydrol. Earth Syst. Sci. Discuss., https://doi.org/10.5194/hess-2018-362

Manuscript under review for journal Hydrol. Earth Syst. Sci.

Discussion started: 29 August 2018

(c) Author(s) 2018. CC BY 4.0 License.
Hydrology and Earth System Sciences

Discussions

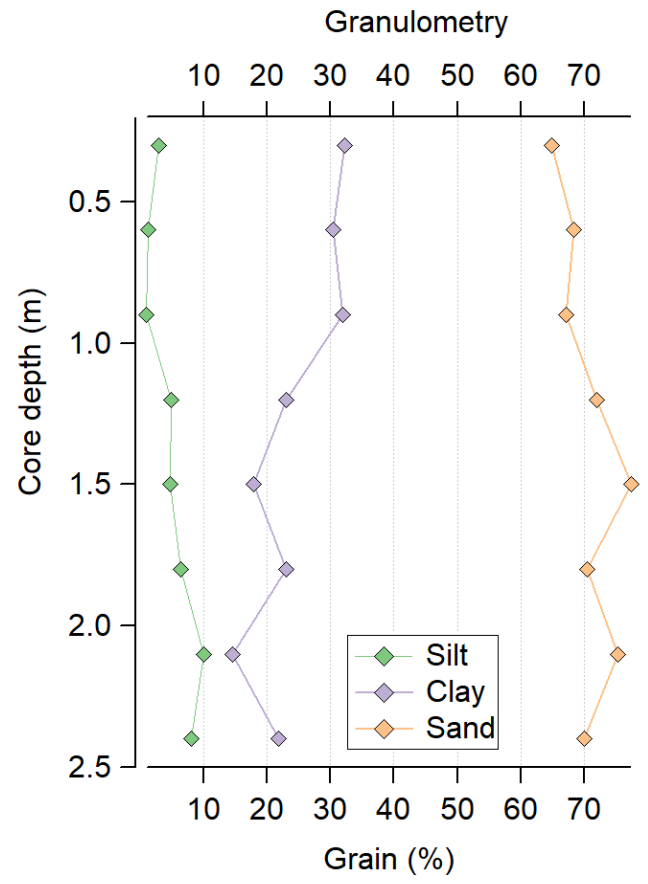

530

Figure 3: Grain size distribution in marine sediments (core GC02).

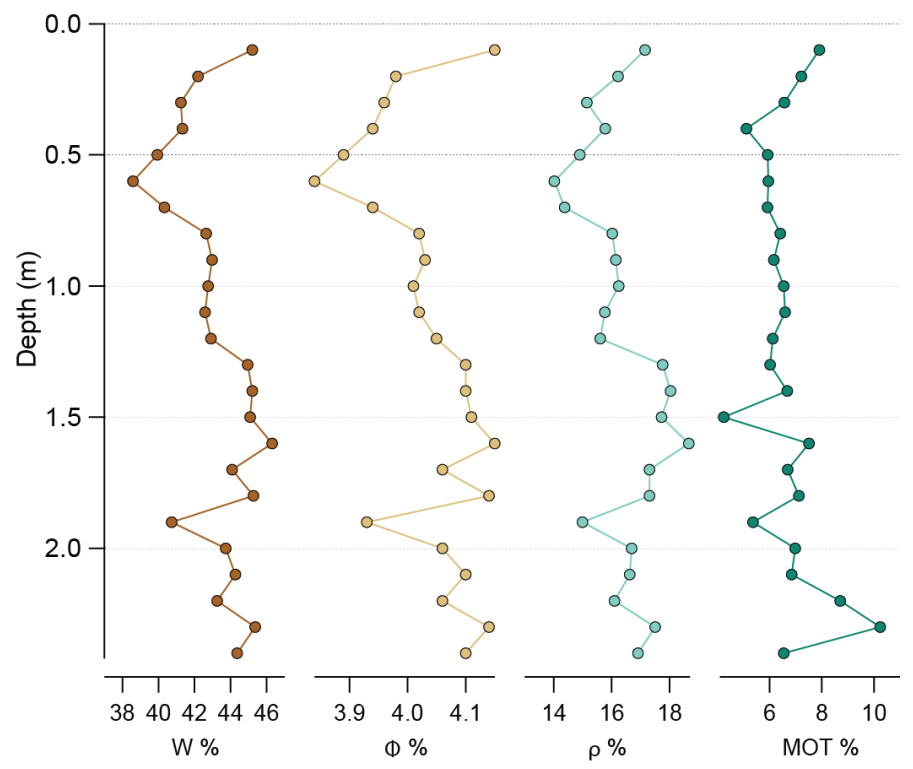

Figure 4: Physical-chemical parameters distribution in marine sediments (core GC02). 
Hydrol. Earth Syst. Sci. Discuss., https://doi.org/10.5194/hess-2018-362

Manuscript under review for journal Hydrol. Earth Syst. Sci.

Discussion started: 29 August 2018

(c) Author(s) 2018. CC BY 4.0 License.
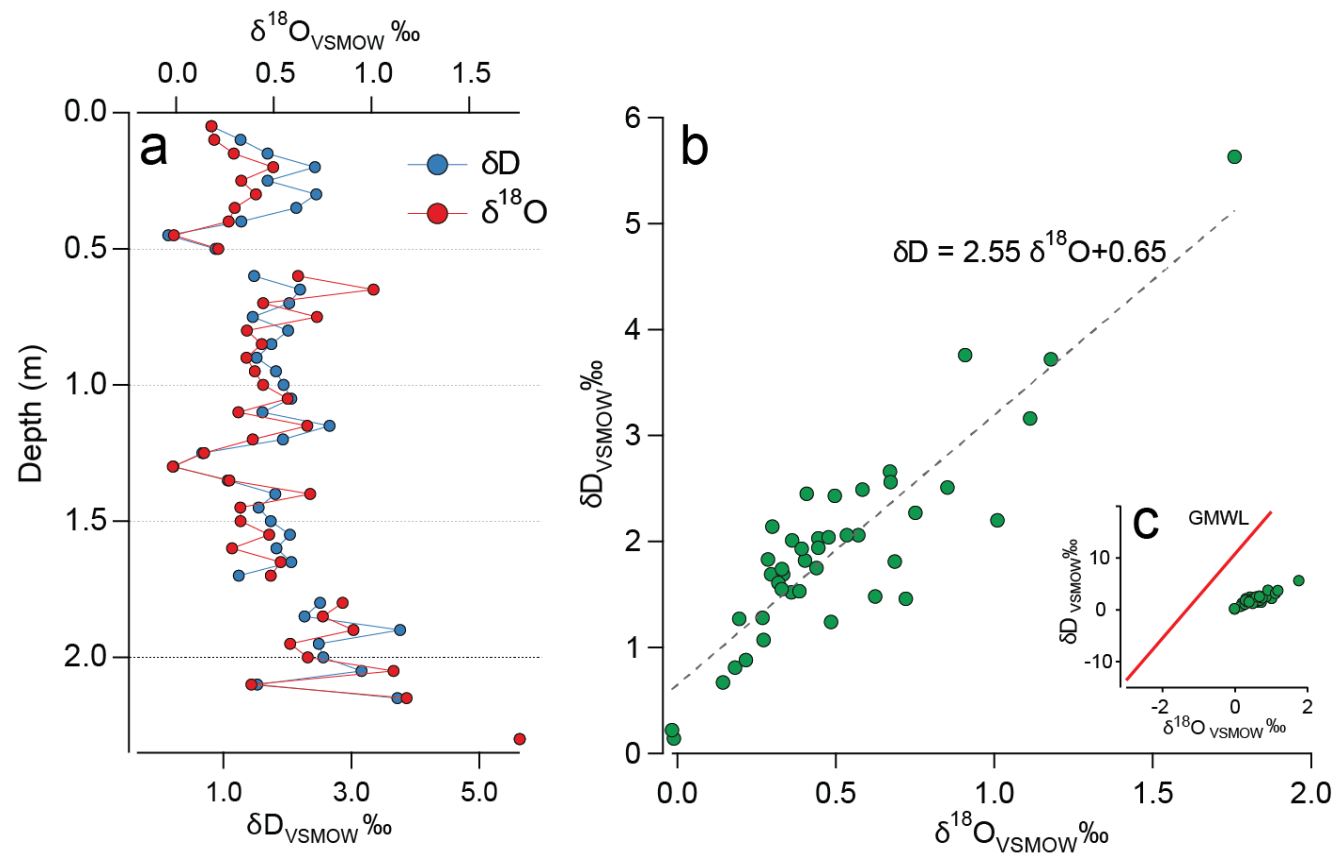

Figure 5. Oxygen $\left(\delta^{18} \mathrm{O}\right)$ and deuterium $(\delta \mathrm{D})$ stable water isotope distribution in sediment from: a. Depth profile of the core; b. co-isotope distribution of the pore water and c. relationship of the co-isotope distribution of pore water samples against the global meteoric water (GMWL) 
Hydrol. Earth Syst. Sci. Discuss., https://doi.org/10.5194/hess-2018-362 Manuscript under review for journal Hydrol. Earth Syst. Sci.

Discussion started: 29 August 2018

(c) Author(s) 2018. CC BY 4.0 License.
Hydrology and

Earth System

Sciences

Discussions

(c) (1)
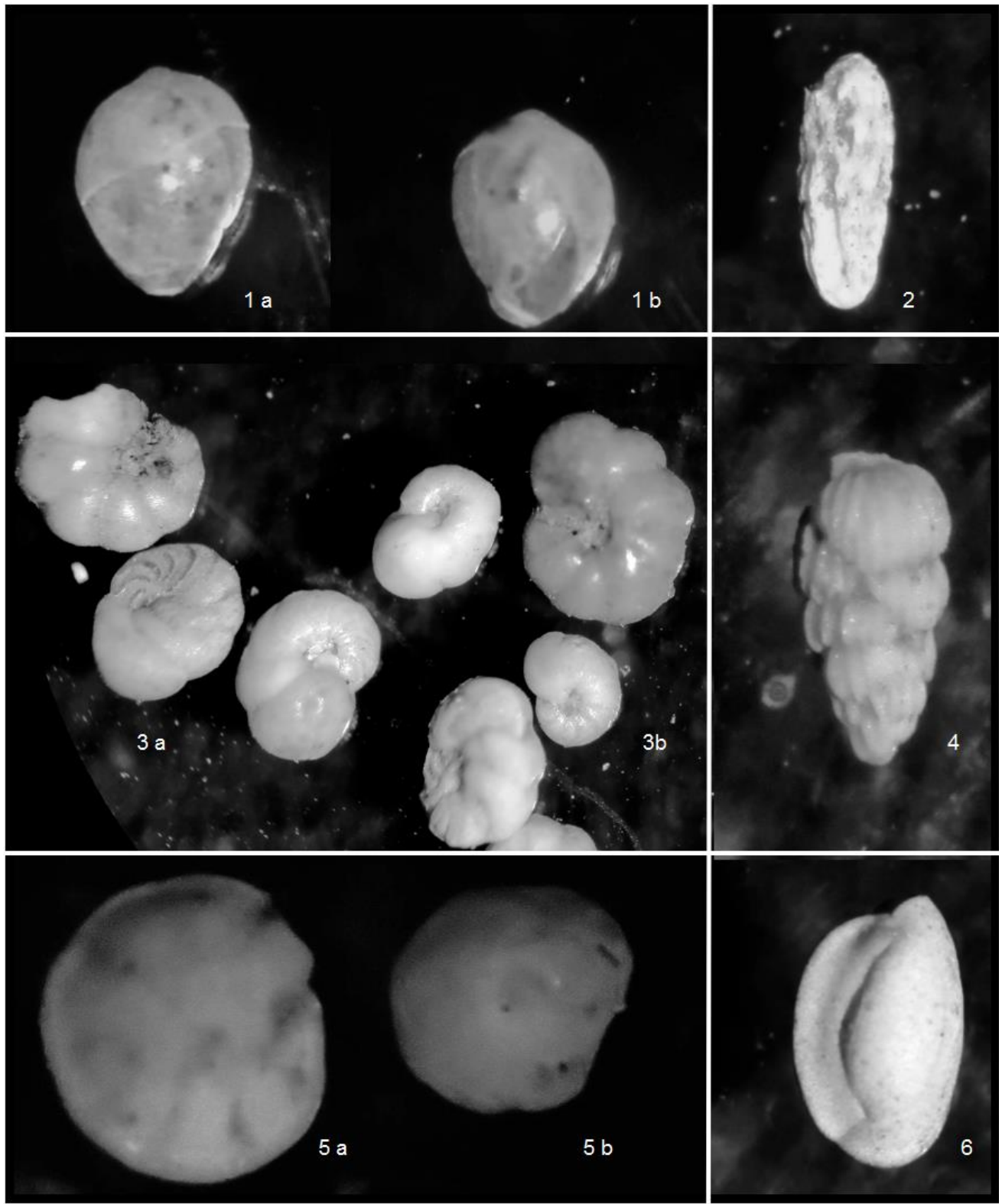

Figure 6: Benthic foraminifera. In (Fig. 1a) Globobulimina, lateral view (10x); (Fig. 1b) Globobulimina, lateral view (10x); (Fig. 2) Bolivina, lateral view (5x); (Fig. 3a) Valvulineria, lateral view (5x); (Fig. 3b) Anomalinoides, lateral view (5x); (Fig. 4) Uvigerina, lateral view (5x); (Fig. 5a) Oridorsalis, lateral view (5x); (Fig. 5b) Oridorsalis, lateral view (5x); (Fig. 6) Quinqueloculina, lateral view (10x). 
Hydrol. Earth Syst. Sci. Discuss., https://doi.org/10.5194/hess-2018-362

Manuscript under review for journal Hydrol. Earth Syst. Sci.

Discussion started: 29 August 2018

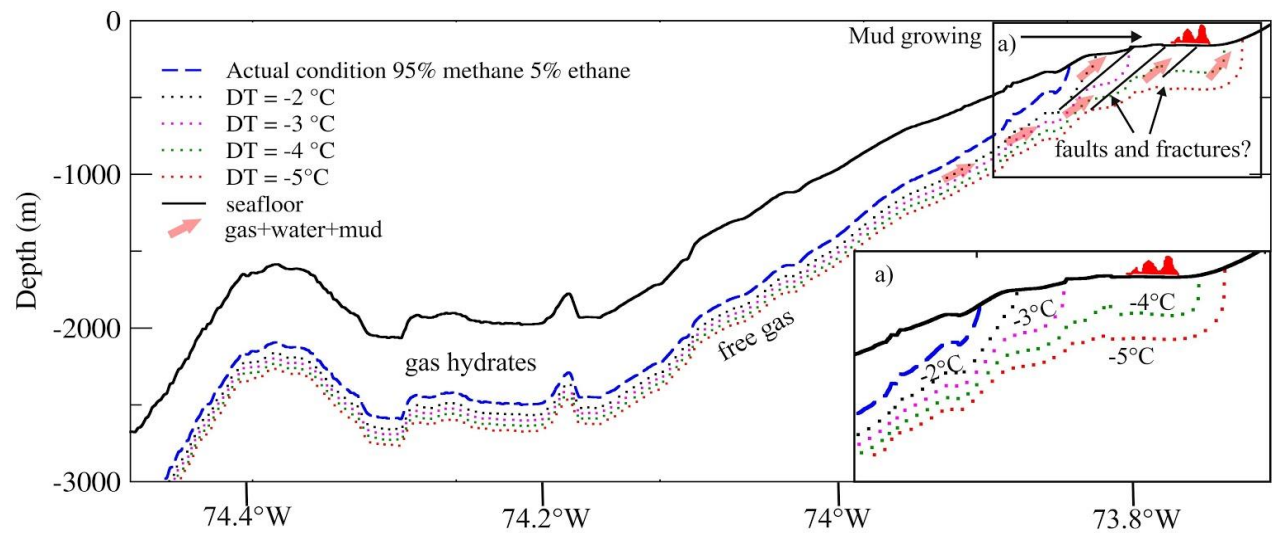

546

547

548

549

550

551

552

553

554

555

556

557

558

559

560

561

562

563

564

565

566

567

568

Figure 7: Schematic profile explaining mud growing formation (in red). The profile location is shown in Fig. 1. Dashed lines show theoretical bases of GHSZ by using geothermal gradient of $30^{\circ} \mathrm{C} / \mathrm{km}$ for several scenarios supposing that the hydrate is formed by a mixture of $95 \%$ of methane and $5 \%$ of ethane. The blue dashed line indicates the actual theoretical base of the GHSZ. The dotted lines indicate the theoretical base of GHSZ supposing a decrease of the bottom temperature of $2{ }^{\circ} \mathrm{C}$ (black dotted line), $3^{\circ} \mathrm{C}$ (magenta dotted line), $4^{\circ} \mathrm{C}$ (green dotted line) and $5{ }^{\circ} \mathrm{C}$ (red dotted line). The black solid line indicates the seafloor. The pink arrows indicate the direction of the fluid/mud outflow. Possible faults and fractures are also reported as black lines. (s)

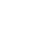


Hydrol. Earth Syst. Sci. Discuss., https://doi.org/10.5194/hess-2018-362

Manuscript under review for journal Hydrol. Earth Syst. Sci.

Discussion started: 29 August 2018

(c) Author(s) 2018. CC BY 4.0 License.
Hydrology and Earth System Sciences

Table 1: Physical-chemical parameter distribution in marine sediments

\begin{tabular}{|c|c|c|c|c|}
\hline Depth (m) & W (\%) & $\phi(\%)$ & $\rho\left(\mathrm{g} / \mathrm{cm}^{3}\right)$ & МOT (\%) \\
\hline 0.1 & 45.2 & 68.8 & 1.6 & 7.9 \\
\hline 0.2 & 42.2 & 66.1 & 1.6 & 7.2 \\
\hline 0.3 & 41.2 & 65.2 & 1.6 & 6.6 \\
\hline 0.4 & 41.3 & 65.3 & 1.6 & 5.1 \\
\hline 0.5 & 39.9 & 64.0 & 1.6 & 5.9 \\
\hline 0.6 & 38.6 & 62.7 & 1.7 & 6.0 \\
\hline 0.7 & 40.3 & 64.4 & 1.6 & 5.9 \\
\hline 0.8 & 42.7 & 66.5 & 1.6 & 6.4 \\
\hline 0.9 & 43.0 & 66.8 & 1.6 & 6.2 \\
\hline 1 & 42.8 & 66.6 & 1.6 & 6.5 \\
\hline 1.1 & 42.6 & 66.5 & 1.6 & 6.6 \\
\hline 1.2 & 42.9 & 66.7 & 1.6 & 6.1 \\
\hline 1.3 & 45.0 & 68.6 & 1.6 & 6.0 \\
\hline 1.4 & 45.2 & 68.8 & 1.6 & 6.7 \\
\hline 1.5 & 45.1 & 68.7 & 1.6 & 4.2 \\
\hline 1.6 & 46.3 & 69.7 & 1.5 & 7.5 \\
\hline 1.7 & 44.1 & 67.8 & 1.6 & 6.7 \\
\hline 1.8 & 45.3 & 68.8 & 1.6 & 7.1 \\
\hline 1.9 & 40.7 & 64.7 & 1.6 & 5.4 \\
\hline 2 & 43.7 & 67.5 & 1.6 & 7.0 \\
\hline 2.1 & 44.3 & 68.0 & 1.6 & 6.8 \\
\hline 2.2 & 43.3 & 67.1 & 1.6 & 8.7 \\
\hline 2.3 & 45.4 & 68.9 & 1.6 & 6.9 \\
\hline 2.4 & 44.4 & 68.0 & 1.6 & 6.5 \\
\hline Average & 43.1 & 66.9 & 1.6 & 6.5 \\
\hline Minimum & 38.6 & 62.7 & 1.5 & 4.2 \\
\hline Maximum & 46.3 & 69.7 & 1.7 & 8.7 \\
\hline
\end{tabular}

